\title{
Підхід до визначення складових теплового навантаження систем кондиціонування припливного повітря
}

\section{Е. І. Трушляков, М. І. Радченко ${ }^{\bowtie}$, А. А. Зубарєв, В. С. Ткаченко}

Національний університет кораблебудування ім. адм. Макарова, проспект Героїв України 9, Миколаїв, 54002, Україна $\triangle$ e-mail: nirad50@gmail.com

\begin{abstract}
Запропоновано підхід до визначення складових теплового навантаження системи кондиціонування припливного повітря (СКПП) з урахуванням поточних кліматичних умов експлуатачії, який базується на гіпотезі розкладання поточних змінних теплових навантажень на відносно стабільну складову як базову для вибору встановленої (проектної) холодопродуктивності холодильної машини, щзо працюєе на номінальних або близьких йому режимах, і нестабільне теплове навантаження, щьо припадає на попереднє охолодження зовнішнього повітря при змінних поточних зовнішніх температурах. Для обтрунтування підходу до вибору складових теплового навантаження СКПП виконаний аналіз поточних значень питомих теплових навантажень на холодильну машину СКПП при охолодженні зовнішнього повітря від його змінної поточної температури до температур 10, 15 i $20{ }^{\circ}$ C. Показано, щуо виходячи з різного темпу приросту річного виробітку холоду, обумовленого зміною теплового навантаження у відповідності з поточними кліматичними умовами протягом року, необхідно вибирати таке проектне теплове навантаження на холодильну машину СКПП охолодження повітря (ії встановлену потужність охолодження), яке забезпечує досягнення максимального або близького йому річного виробітку холоду при відносно високих темпах його збільшення. При цฺьому значення теплового навантаження, щзо припадає на попереднє охолодження зовнішнього повітря, розраховують за залишковим принципом як різницю раціонального загального теплового навантаження і ї̈ базової відносно стабільної складової. Запропонований метод доцільно використовувати при розрахунку проектної базової холодопродуктивності холодильної машини СКПП, щчо працює на номінальному або близьких йому режимах, і бустерной складової теплового навантаження на попереднс охолодження зовнішнього повітря при змінних поточних зовнішніх температурах з використанням енергозберігаючих методів: акумуляиії надлишкового (невикористаного) холоду при знижених поточних теплових навантаженнях на СКПП $і$ його витрачання на попереднс охолодження зовнішнього повітря, річкупераціі охолоджуючого потенціалу повітря, яке відводиться для попереднього охолодження зовнішнього повітря.
\end{abstract}

Ключові слова: кондиціювання, зовнішне повітря, теплове навантаження, холодильна машина, кліматичні умови

(C) The Author(s) 2018. This article is an open access publication

This work is licensed under the Creative Commons Attribution 4.0 International License (CC BY) http://creativecommons.org/licenses/by/4.0/

\section{1. Аналіз проблеми і постановка мети дослі- дження}

Експлуатація систем кондиціонування припливного повітря (СКПП) характеризується значними коливаннями теплового навантаження, відповідно і енергоспоживання $[1,2]$. Крім внутрішніх тепло- і вологовиділень і теплопритоків ззовні енергозатрати на обробку повітря в значній мірі визначаються тепловологими параметрами зовнішнього повітря (температурою $t_{\mathrm{нв}}$ відносною вологістю $\left.\varphi_{\text {нв }}\right)$. Енерговитрати на тепловологу обробку зовнішнього повітря цілком визначаються поточними кліматичними умовами і характеризуються коливання теплового навантаження на повітроохолоджувачі (ВО) СКПП і відповідно систему холодопостачання. Тому проблема вибору встановленої (проектної) холодопродуктивності $Q_{0}$ холодильних машин (ХМ) СКПП в умовах нерівномірних теплових навантажень стоїть дуже гостро, і від іï вирішення залежить ефективність використання встановлених холодильних потужностей, тобто тривалість експлуатації ХМ в році.

Мета дослідження - розробити підхід до визначення складових теплового навантаження СКПП з урахуванням іiі зміни відносно до поточних кліматичних умов.

\section{2. Результати дослідження}

Ефективність роботи систем кондиціонування повітря, як і будь-який енергогенеруючої установки, визначається кількістю виробленої енергії (в нашому випадку - холоду) за певний період, наприклад рік, і витратами на iї виробництво. Цілком очевидно, що кількість виробленого холоду відповідає його споживанню і в разі СКПП - витрачання на тепловологу обробку (кондиціонування) припливного повітря, яке залежить від поточних тепловологових параметрів зовнішнього повітря (температури $t_{\text {нв }}$ та відносної волого- 
сті $\left.\varphi_{\text {нв }}\right)$ і глибини його охолодження, а також тривалості $\tau$ роботи СКПП.

3 огляду на це про ефективність використання СКПП можна судити по використанню встановленої (проектної) холодопродуктивності іiі холодильної машини (XМ), яку в свою чергу оцінювати річним виробленням холоду (річною холодопродуктивністю) $\sum\left(Q_{0} \cdot \tau\right), \quad$ кВт.г, де $Q_{0} \quad$ - поточна холоддопродуктивність (теплове навантаження) ХМ, кВт.

3 метою узагальнення результатів і зручності перерахунку на інші холодильні потужності холодопродуктивність ХМ СКПП зручно представляти не в абсолютних, а у відносних (питомих) величинах, що припадають на одиничну витрату повітря $\left(G_{\mathrm{B}}=1 \kappa \Gamma / \mathrm{c}\right)-\mathrm{y}$ вигляді питомого теплового навантаження, або холодопродуктивності, $q_{0}=Q_{0} / G_{\mathrm{B}}$, кВт / (кг / с), або кДж / кг, де $Q_{0}$ - повне теплове навантаження (холодопродуктивність) при охолодженні повітря витратою $G_{\text {в }}$ : $Q_{0}=\left(c_{\text {вл }} \xi \cdot \Delta t_{\text {в }}\right) G_{\text {в }}, c_{\text {вл }}-$ теплоємність вологого повітря; $\xi$ - коефіцієнт вологовипадіння; $\Delta t_{\mathrm{B}}-$ зниження температури повітря [3].

Аналогічним чином представляють і дані по річному виробництву холоду (річної холодопродуктивності) у відносних (питомих) величинах, що припадають на одиничну витрату повітря: $\sum\left(q_{0} \cdot \tau\right)=\sum\left(Q_{0} \cdot \tau\right) / G_{\text {в }}$, $\kappa В \mathrm{\tau} \cdot ч /(\kappa г / \mathrm{c})$.

Значення питомого (при $G_{\mathrm{B}}=1$ кг/с) річного виробітку холоду (річної холодопродуктивності) $\sum\left(q_{0} \cdot \tau\right)$ в залежності від питомої встановленої холодопродуктивності $\mathrm{XM} q_{0}$ при різних температурах охолодженого повітря $t_{\mathrm{B} 2}: t_{\mathrm{B} 2}=10,15$ и $20^{\circ} \mathrm{C}$, для кліматичних умов м Вознесенськ, Миколаївська обл. 2017 р., наведені на рисунку 1.

$\Sigma\left(q_{0} \cdot \tau\right), 10^{3} \kappa \mathrm{KT} \cdot \mathrm{ч} /(\kappa \Gamma / \mathrm{c})$

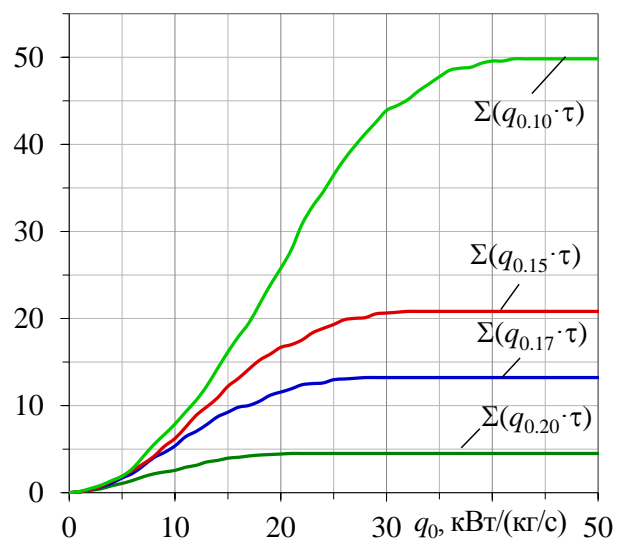

Рисунок 1 - Значення питомого річного виробітку холоду $\sum\left(q_{0} \cdot \tau\right)$ в залежності від питомої встановленої холодопродуктивності ХM $q_{0}: \sum\left(q_{0}{ }^{\circ} \tau\right)_{10 ; 15 ; 20}$ при $t_{62}=$ $=10 ; 15$ u $20{ }^{\circ} \mathrm{C}$

Як видно, для розглянутих кліматичних умов при охолодженні повітря до температури $t_{\mathrm{B} 2}=10^{\circ} \mathrm{C}$ в СКП 3 холодильною машиною встановленої питомої (при $G_{\text {в }}=1$ кг/c) холодопродуктивністю $q_{0}=35 \mathrm{\kappa BT} /(\kappa г / \mathrm{c})$ величина питомого вироблення холоду $\sum\left(q_{0} \cdot \tau\right)$ за 2017 p складає 48 кВт.ч/(кг/c), причому при збереженні високих темпів іiі нарощування. Через падіння темпів приросту $\sum\left(q_{0} \cdot \tau\right)$ для ХМ холодопродуктивністю $q_{0}$ більше 35 кВт / (кг / с) помітного зростання $\sum\left(q_{0} \cdot \tau\right)$ не відбувається. Питому холодопродуктивність ХМ $q_{0}=$ $=35 \mathrm{\kappa BT} /(\kappa г / \mathrm{c})$ приймають за раціональну і виходячи 3 неї вибирають повну встановлену холодильну потужність ХМ для витрати повітря $G_{\mathrm{B}}: Q_{0}=$ $G_{\text {в }} \cdot q_{0}$, кВт. Застосування ХМ більшої холодильної потужності $q_{0}: q_{0}>35$ кВТ/(кг/с), не призводить до помітного збільшення $\sum\left(q_{0} \cdot \tau\right)$, але викликає зростання вартості на $20 \ldots 30 \%$. Відповідно при охолодженні повітря до температури $t_{\mathrm{B} 2}=15^{\circ} \mathrm{C}$ за раціональну приймають питому холодопродуктивність ХМ $q_{0}=$ $=25 \mathrm{\kappa BT} /(\kappa г / \mathrm{c})$, а до $t_{\mathrm{B} 2}=20{ }^{\circ} \mathrm{C}-$ величину $q_{0}=$ $=15 \kappa \mathrm{\kappa T} /(\kappa \Gamma / \mathrm{c})$..

Підтвердженням правомірності такого вибору значень раціональної встановленої (проектної) питомої холодопродуктивності $q_{0.10 \text { рац }}$ і $q_{0.15 \text { рац }}$ служать результати їх порівняння 3 поточними значеннями питомих теплових навантажень відповідно $q_{0.10}$ і $q_{0.15}$ при охолодженні повітря до температур $t_{\text {в2 }}=10$ и $15^{\circ} \mathrm{C}$ (рис .2).
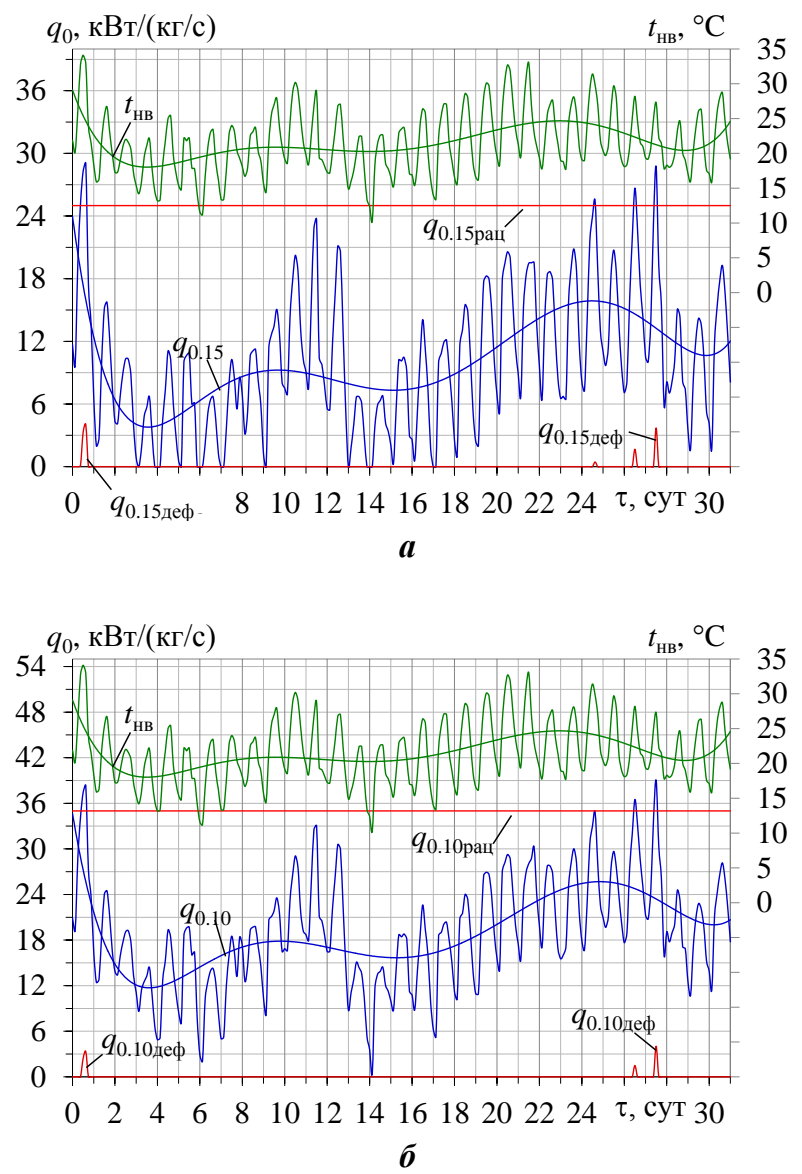

Рисунок 2 - Поточні значення температури зовнішнього повітря $t_{\text {нв }}$, питомого теплового навантаження $q_{0.15}$ охолодження повітря від температури $t_{н в}$ до $t_{62}=$ $15{ }^{\circ} \mathrm{C}$, раціонального проектного питомого теплового навантаження $q_{0.15 \text { рач }}=25 \mathrm{\kappa Bm} /(\kappa 2 / c) \quad i$ дефіициту

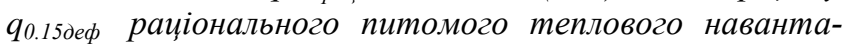

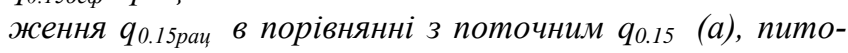
мим тепловим навантаженням $q_{0.10}$ охолодження повітря від температури $t_{н в}$ до $t_{62}=10{ }^{\circ} \mathrm{C}$, раціонального проектного (питомого) теплового навантаження

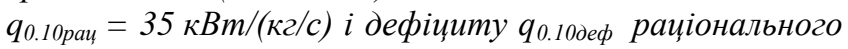

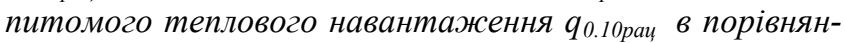
ні з поточним $q_{0.10}$ (б). 
У найбільш спекотні періоди буде мати місце деякий дефіцит (недолік) питомої холодопродук-

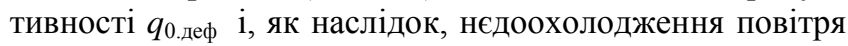
до температури $t_{\mathrm{B} 2}=10^{\circ} \mathrm{C}$ або $t_{\mathrm{B} 2}=15^{\circ} \mathrm{C}$, оскільки значення раціональної встановленої (проектної) питомої холодопродуктивності $q_{0.10 \text { рац }}$ i $q_{0.15 \text { раи }}$ обрані трохи менше максимального теплового навантаження, що зустрічається в перебігу року (рис. 1). При цьому дефіцит питомої холодопродуктивності обчислювали як $q_{0.10 \text { деф }}=q_{0.10}-q_{0.10 \text { рац }} \mathrm{i} q_{0.15 \text { деф }}=q_{0.15}-q_{0.15 \text { рац }}$.

3 рис. 2 видно, що раціональних питомих холодопродуктивностей $\quad q_{0.10}=35 \mathrm{\kappa BT} /(\kappa \Gamma / c) \quad$ и $\quad q_{0.15}=$ $=25 \mathrm{\kappa BT} /(\kappa \Gamma / \mathrm{c})$, розрахованих виходячи з річної холодопродуктивності (рис. 1), досить для охолоджування зовнішнього повітря від $t_{\text {нв }}$ до $t_{\text {нв }}$ до $t_{\mathrm{B} 2}=10$ и $15^{\circ} \mathrm{C}$ практично протягом усього липня 2017, крім проміжків по 2 ... 3 години 1, 27, 28 липня.

Для обгрунтування підходу до вибору раціонального теплового навантаження СКПП виконаний аналіз поточних значень питомих теплових навантажень $q_{0}$ на ХМ СКПП при охолодженні зовнішнього повітря від поточної температури $t_{\text {нв }}$ до $t_{\mathrm{B} 2}=10,15$ и $20^{\circ} \mathrm{C}$, відповідно $q_{0.10}, q_{0.15}$ и $q_{0.20}$, а 3 метою підтвердження гіпотези про можливість виділення з поточних змінних теплових навантажень відносно стабільної складової розраховані різниці теплових навантажень $q_{0.10-15}=$ $=q_{0.10}-q_{0.15}$ и $q_{0.10-20}=q_{0.10}-q_{0.20}$ для найбільш теплого липня місяця 2017 року (рис. 3-10).

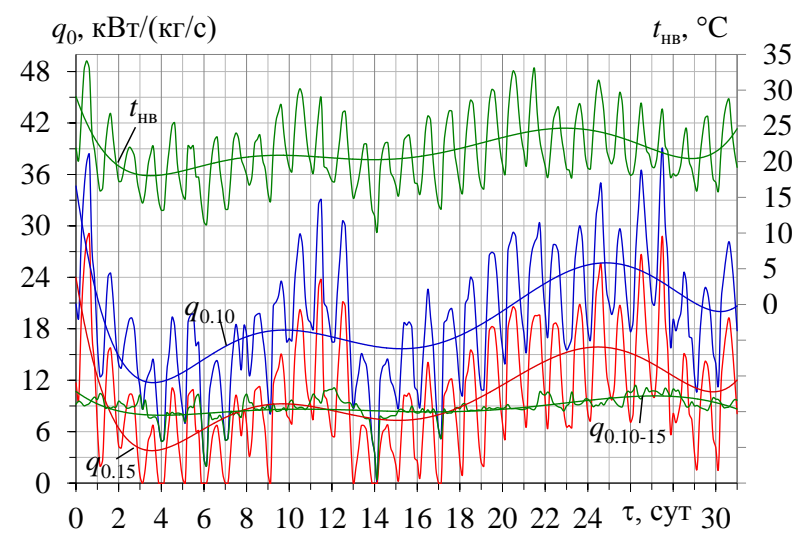

Рисунок 3 - Поточні значення температури зовнішнього повітря $t_{\text {нв }}$ питомих теплових навантажень на СКПП $q_{0.10}$ и $q_{0.15}$ при охолодженні зовнішнього повітря від його поточної температури $t_{н в}$ до $t_{62}=10$ i $15^{\circ} \mathrm{C}$ відповідно, а також їх різниці $q_{0.10-15}=q_{0.10}-q_{0.15}$

Як видно, при охолодженні зовнішнього повітря від $t_{\text {нв }}$ до $t_{\text {в } 2}=15^{\circ} \mathrm{C}$ коливання поточного теплового навантаження на ПО СКПП $q_{0.15}$ вельми значні. У той же час при доохолодженні повітря від проміжної температури $t_{\mathrm{B} 2}=15^{\circ} \mathrm{C}$ до $t_{\mathrm{k} 2}=10^{\circ} \mathrm{C}$ коливання теплового навантаження на ПО СКПП $q_{0.10-15}=q_{0.10}-q_{0.15}$ порівняно невеликі: $9 \ldots 11 \kappa \mathrm{\kappa T} /(\kappa г / \mathrm{c})$, беручи до уваги 3-5 короткочасних сплесків-падінь величини $q_{0.10-15}$, обумовлених, як буде показано нижче, коливаннями поточних теплових навантажень $q_{0.15}$.

Таким чином, характер теплового навантаження на ПО СКПП різний: значні зміни теплового навантаження $q_{0.15}$ попереднього охолодження зовнішнього повітря від $t_{\text {нв }}$ до проміжної температури $t_{\mathrm{B} 2}=15^{\circ} \mathrm{C}$ i відносно стабільне теплове навантаження $q_{0.10-15}$ при глибокому охолодженні повітря від $t_{\mathrm{B} 2}=15^{\circ} \mathrm{C}$ до $t_{\mathrm{B} 2}=$ $=10^{\circ} \mathrm{C}$.

3 урахуванням відносно стабільного характеру питомого теплового навантаження на ПО СКПП $q_{0.10-15}=$ $=q_{0.10}-q_{0.15}$ при охолодженні повітря від температури $t_{\mathrm{B} 2}=15^{\circ} \mathrm{C}$ до $t_{\mathrm{B} 2}=10^{\circ} \mathrm{C}$ в порівнянні з охолодженням зовнішнього повітря від $t_{\text {нв }}$ до $t_{\mathrm{B} 2}=15^{\circ} \mathrm{C}$ іiі доцільністьно приймати в якості проектної для глибокого охолодження повітря від $t_{\mathrm{B} 2}=15^{\circ} \mathrm{C}$ до $t_{\mathrm{B} 2}=10^{\circ} \mathrm{C}$. Відповідно, теплове навантаження, що припадає на попереднє охолодження зовнішнього повітря від поточної температури $t_{\text {нв }}$ до $t_{\text {нв }}$ до $t_{\mathrm{B} 2}=15^{\circ} \mathrm{C}$ (назвемо його бустерним ступенем охолодження зовнішнього припливного повітря) можна визначати за залишковим принципом: як різниця між раціональном тепловим навантаженням

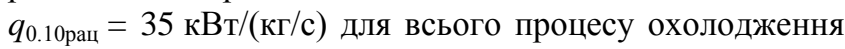
повітря від поточної $t_{\text {нв }}$ до $t_{\mathrm{в} 2}=10^{\circ} \mathrm{C}$, що забезпечує близький максимальному річний виробіток холоду $\sum\left(q_{0} \cdot \tau\right) \approx 48 \mathrm{\kappa BT} \cdot ч /(\kappa г / \mathrm{c})$ (рис. 1$)$, і його стабільної соскладової у вигляді різниці теплових навантажень $q_{0.10-15}=q_{0.10}-q_{0.15}$, тобто як $q_{0.510-15}=35-q_{0.10-15}$ (рис. 4).

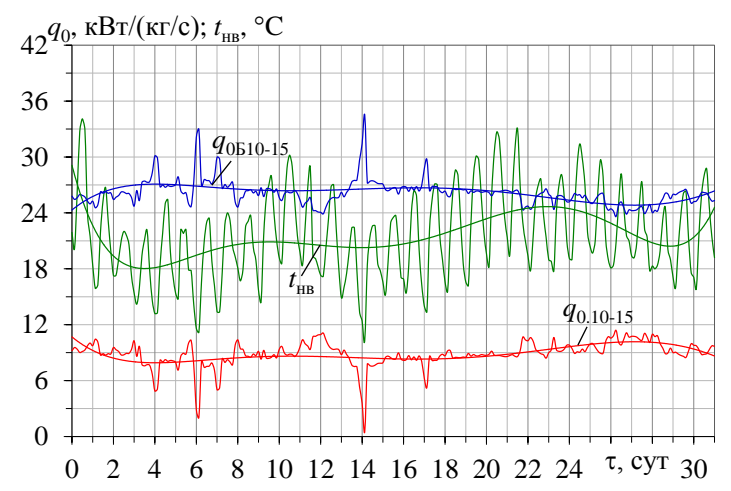

Рисунок 4 - Поточні значення температури зовнішнього повітря $t_{\text {нв }}$ питомого теплового навантаження $q_{0.10-15}=q_{0.10}-q_{0.15}$ глибокого охолодження повітря від температури $t_{62}=15^{\circ} \mathrm{C}$ до $t_{62}=10^{\circ} \mathrm{C}$, теплового навантаження $q_{0.510-15}=35-q_{0.10-15}$ попереднього охолодження зовнішнього повітря від $t_{н в}$ до $t_{62}=15^{\circ} \mathrm{C}$, розрахованої за залишковим принциипом

Як видно, графік питомого теплового навантаження $q_{0.510-15}=35-q_{0.10-15}$ попереднього охолодження зовнішнього повітря від $t_{\text {нв }}$ до $t_{\mathrm{B} 2}=15^{\circ} \mathrm{C}$, розрахованої за залишковим принципом як $q_{0.510-15}=35-q_{0.10-15}, \mathrm{e}$ дзеркальним відображенням графіка питомого теплового навантаження $q_{0.10-15}=q_{0.10}-q_{0.15}$ глибокого охолодження повітря від температури $t_{\mathrm{B} 2}=15^{\circ} \mathrm{C}$ до $t_{\mathrm{B} 2}=$ $=10^{\circ} \mathrm{C}$.

Про те, що причиною короткочасних сплесківпадінь величин $q_{0.10-15} \mathrm{i} q_{0.510-15}, \epsilon$ коливання поточних теплових навантажень $q_{0.15}$ попереднього охолодження зовнішнього повітря від $t_{\text {нв }}$ до $t_{\mathrm{B} 2}=15^{\circ} \mathrm{C}$, служать результати розрахунків на рис. 5 і 6 .

Як видно 3 рис. 5, сплески (надлишок) поточних значень питомого теплового навантаження $q_{0.510-15}$ попереднього охолодження зовнішнього повітря від 
його поточної температури $t_{\mathrm{Hв}}$ до $t_{\mathrm{B} 2}=15^{\circ} \mathrm{C}$ понад i проектної величини мають місце при падінні поточного питомого теплового навантаження $q_{0.15}$ до нуля i, навпаки, найбільші зниження (дефіцит проектного теплового навантаження) поточної величини $q_{0.510-15}$ відбуваються при максимальних поточних теплових навантаженнях $q_{0.15}$, що перевищують проектну величину для попереднього охолодження зовнішнього повітря від його поточної температури $t_{\mathrm{Hв}}$ до $t_{\mathrm{B} 2}=15^{\circ} \mathrm{C}$.

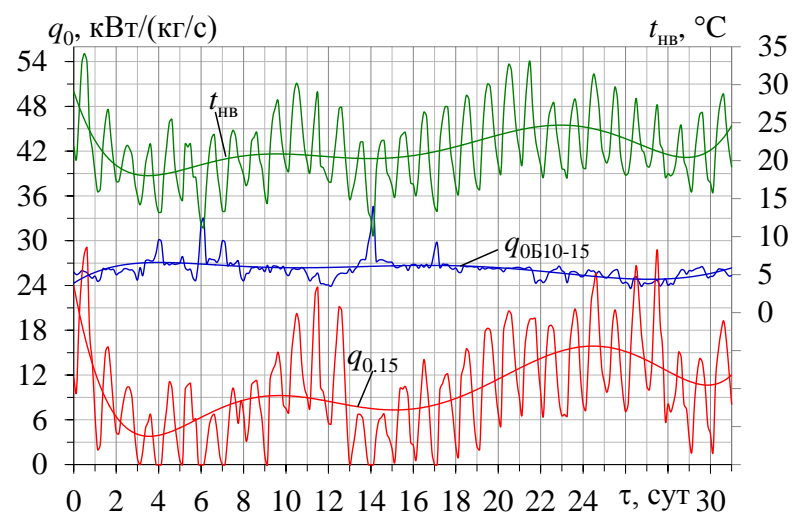

Рисунок 5 - Поточні значення температури зовнішнього повітря $t_{н в}$, питомого теплового навантаження $q_{0.15}$ попереднього охолодження зовнішнього повітря від його поточної температури $t_{н в}$ до $t_{62}=15{ }^{\circ} \mathrm{C}$ i menлового навантаження попереднього охолодження повітря $q_{0.510-15}=35-q_{0.10-15}$, розрахованої за залишковим принциипом

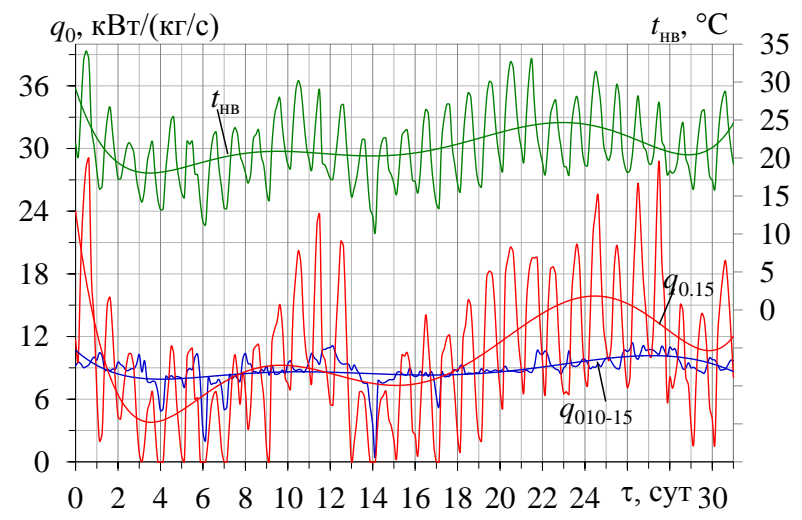

Рисунок 6 - Поточні значення температури зовнішнього повітря $t_{\text {нв }}$, питомого теплового навантаження $q_{0.5}$ попереднього охолодженні зовнішнього повітря від його поточної температури $t_{н в}$ до $t_{62}=15^{\circ} \mathrm{C} i$ теплового навантаження $q_{0.10-15}=q_{0.10}-q_{0.15}$ глибокого охолодження повітря від $t_{62}=15^{\circ} \mathrm{C}$ до $t_{62}=10{ }^{\circ} \mathrm{C}$

Дефіцит (брак) проектного теплового навантаження попереднього охолодження зовнішнього повітря в порівнянні 3 поточним навантаженням $q_{0.510-15}$ супроводжується відповідним зростанням теплового навантаження $q_{0.10-15}=q_{0.10}-q_{0.15}$ глибокого охолодження повітря від температури трохи вище $15^{\circ} \mathrm{C}$ до температури $t_{\mathrm{B} 2}=10^{\circ} \mathrm{C}$ з утворенням відповідно їі дефіциту у вигляді перевищення проектної величини поточними навантаженнями $q_{0.10-15}=q_{0.10}-q_{0.15}$, що має місце при підвищених температурах зовнішнього повітря $t_{\text {нв }}$ (рис. 6). I навпаки, надлишок проектного теплового навантаження глибокого охолодження повітря понад поточних величин $q_{0.10-15}=q_{0.10}-q_{0.15}$ у вигляді падіння останніх аж до нуля відбувається при знижених температурах зовнішнього повітря $t_{\mathrm{Hв}}$ нижче $15^{\circ} \mathrm{C}$.

3 рис.6 видно, що вибір проміжної температури охолодженого зовнішнього повітря $t_{\mathrm{B} 2}=15^{\circ} \mathrm{C}$ в якості "порогового" іiі значення між попереднім охолодженням зовнішнього повітря, що характеризується значними коливаннями теплового навантаження $q_{0.15}$, і наступним доохолодженні повітря від $t_{\mathrm{B} 2}=15^{\circ} \mathrm{C}$ до $t_{\mathrm{B} 2}=10^{\circ} \mathrm{C}$ цілком коректний, про що свідчить відносно стабільний характер теплового навантаження $q_{0.10-15}=q_{0.10}-q_{0.15}$ (рис. 3 i 4).

Очевидно, що чим вужчий діапазон змінних теплових навантажень, тобто чим вище граничне значення температури попереднього охолодження зовнішнього повітря, тим більше тривалість експлуатації холодильної машини бустерной ступені попереднього охолодження повітря в році при величинах теплового навантаження (холодопродуктивності), близьких номінальної.

3 метою визначення верхньої межі для порогового значення температури попереднього охолодження зовнішнього повітря були виконані розрахунки процесів охолодження зовнішнього повітря від $t_{\text {нв }}$ до більш високої проміжної температури $t_{\mathrm{B} 2}=20^{\circ} \mathrm{C}$ і відповідних теплових навантажень на подальше доохолодження повітря $q_{0.10-20}=q_{0.10}-q_{0.20}$ від $t_{\mathrm{B} 2}=20^{\circ} \mathrm{C}$ до $t_{\mathrm{B} 2}=10^{\circ} \mathrm{C}$ (рис. 7).

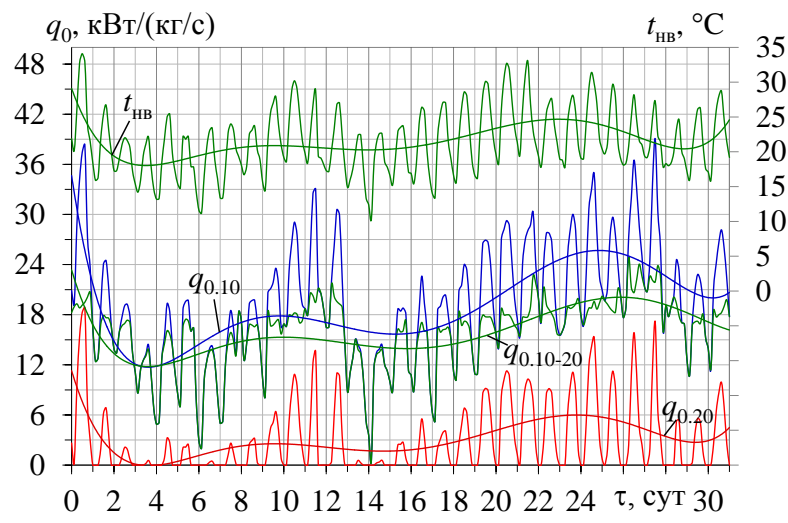

Рисунок 7 - Поточні значення температури зовнішнього повітря $t_{\text {нв }}$, питомих теплових навантажень на ВО СКПП $q_{0.10} i q_{0.20}$ при охолодженні зовнішнього повітря від його поточної температури $t_{н в}$ до $t_{62}=10 u$ $20{ }^{\circ} \mathrm{C}$ відповідно, а також їх різниці $q_{0.10-20}=q_{0.10}-q_{0.20}$

Як видно 3 рис. 7, теплове навантаження СКПП $q_{0.10-20}=q_{0.10}-q_{0.20}$ на доохолодження повітря від $t_{\mathrm{B} 2}=20^{\circ} \mathrm{C}$ до $t_{\mathrm{B} 2}=10^{\circ} \mathrm{C}$ вельми нестабільна. Це викликано більш раннім (при більш високій проміжній температурі $t_{\text {в2 }}$ ) падінням до нуля теплового навантаження $q_{0.20}$ на ПО попереднього охолодження зовнішнього повітря, обумовленим звуженням діапазону температур $\Delta t_{20}=t_{\text {нв }}-20^{\circ} \mathrm{C}$ охолодженні зовнішнього повітря при підвищеної проміжної температурі $t_{\mathrm{B} 2}=20^{\circ} \mathrm{C}$ (в порівнянні $\Delta t_{15}=t_{\text {нв }}-15^{\circ} \mathrm{C}$ при $\left.t_{\mathrm{B} 2}=15^{\circ} \mathrm{C}\right)$, наслідком чого $\epsilon$ 
відповідне збільшення теплового навантаження $q_{0.10-20}=$ $q_{0.10}-q_{0.20}$ на подальше доохлодження повітря від температури $t_{\mathrm{B} 2}=20^{\circ} \mathrm{C}$ до $t_{\mathrm{B} 2}=10^{\circ} \mathrm{C}$ (рис. 8).

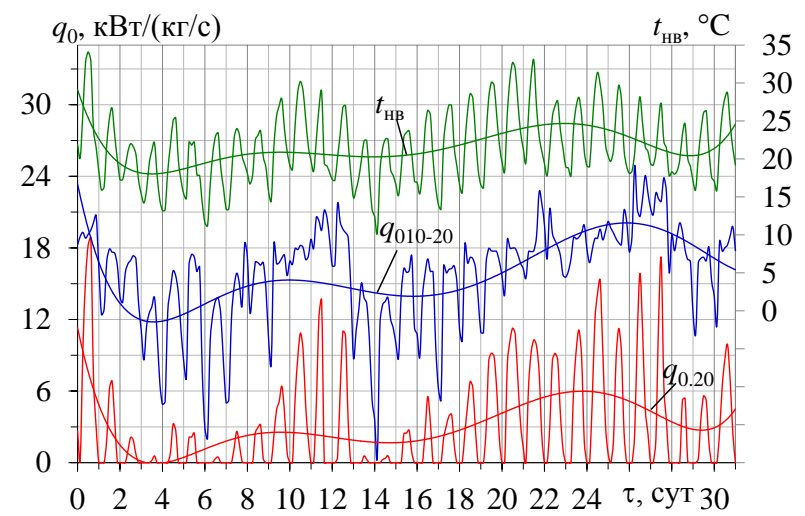

Рисунок 8 - Поточні значення температури зовнішнього повітря $t_{\text {нв }}$, питомого теплового навантаження $q_{0.20}$ попереднього охолодженні зовнішнього повітря від його поточної температури $t_{н в}$ до $t_{62}=20{ }^{\circ} \mathrm{C}$ i menлового $q_{0.10-20}=q_{0.10}-q_{0.20}$ доохолодження повітря від $t_{62}=20{ }^{\circ} \mathrm{C}$ до $t_{62}=10^{\circ} \mathrm{C}$

При цьому теплове навантаження $q_{0.10-20}=$ $=q_{0.10}-q_{0.20}$ доохолодження повітря від температури $t_{\mathrm{B} 2}=20^{\circ} \mathrm{C}$ до $t_{\mathrm{B} 2}=10^{\circ} \mathrm{C}$ практично в два рази більше в порівнянні 3 величиною $q_{0.10-15}=q_{0.10}-q_{0.15}$ охолодження повітря від $t_{\mathrm{B} 2}=15^{\circ} \mathrm{C}$ до $t_{\mathrm{B} 2}=10^{\circ} \mathrm{C}$, тобто на $10^{\circ} \mathrm{C}$ проти $5^{\circ} \mathrm{C}$.

Наслідком знижених теплових навантажень $q_{0 . Б 10-20}$ і $q_{0.20}$ попереднього охолодження зовнішнього повітря через звуження їх діапазону при більш високій проміжній температурі $t_{\mathrm{B} 2}=20^{\circ} \mathrm{C} \epsilon$ передача решти змінних навантажень від ступеня попереднього охолодження зовнішнього повітря на щабель доохолодження повітря (рис. 9).

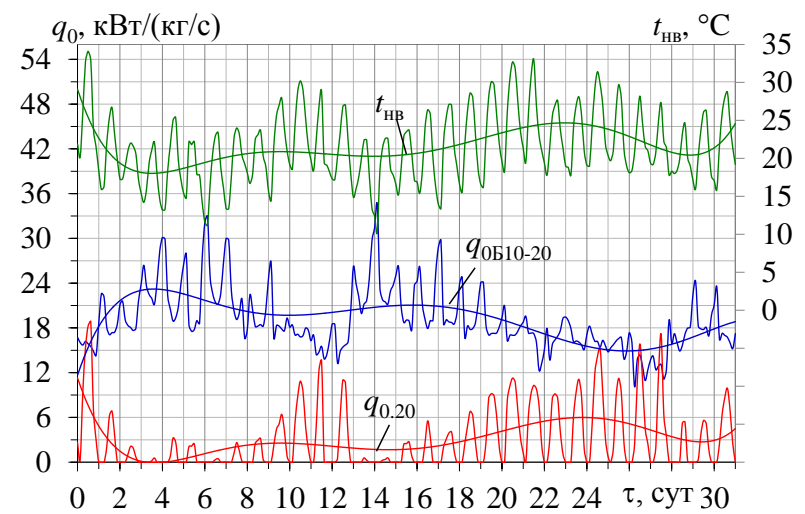

Рисунок 9 - Поточні значення температури зовнішнього повітря $t_{\text {нв }}$, питомого теплового навантаження $q_{0.20}$ попереднього охолодження зовнішнього повітря від його поточної температури $t_{н в}$ до $t_{62}=20{ }^{\circ} \mathrm{C} i$ теплового навантаження попереднього охолодження повітря $q_{0.510-20}=34-q_{0.10-20}$, розрахованої за залишковим принцииом

В результаті порівняння питомих теплових навантажень глибокого охолодження повітря $q_{0.10-15}=$ $=q_{0.10}-q_{0.15}$ и $q_{0.10-20}=q_{0.10}-q_{0.20}$ можна зробити висновок, що стабілізація теплового навантаження відбувається в результаті попереднього охолодження зовнішнього повітря до більш низької проміжної температури $t_{\mathrm{B} 2}=15^{\circ} \mathrm{C}$ в порівнянні $3 t_{\mathrm{B} 2}=20^{\circ} \mathrm{C}$.

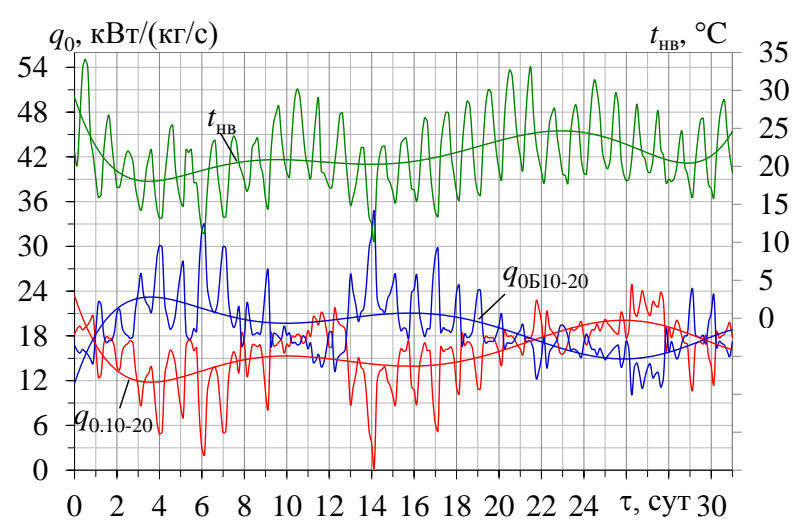

Рисунок 10 - Поточні значення температури зовнішнього повітря $t_{\text {нв}}$, питомого теплового навантаження $q_{0.10-20}=q_{0.10}-q_{0.20}$ глибокого охолодження повітря від температури $t_{62}=20{ }^{\circ} \mathrm{C}$ до $t_{62}=10^{\circ} \mathrm{C}$, теплового навантаження $q_{0.510-20}=34-q_{0.10-20}$ попереднього охолодження зовнішнього повітря від $t_{н в}$ до $t_{62}=20^{\circ} \mathrm{C}$, розрахованої за залишковим принщипом

Таким чином, теплове навантаження $q_{0.10-15}=$ $=q_{0.10}-q_{0.15}$ слід приймати в якості базового, що забезпечує ефективну роботу ХМ в режимі, близькому номінальному, і виходячи 3 нього розраховувати теплове навантаження попереднього охолодження повітря $q_{0.510-15}$ до температури $t_{\mathrm{B} 2}=15^{\circ} \mathrm{C}$ за залишковим принципом як $q_{0 . \mathrm{Б} 10-15}=q_{0.10 \mathrm{paц}}-q_{0.10-15}$.

\section{Висновки}

Запропоновано підхід до визначення складових теплового навантаження СКПП з урахуванням поточних кліматичних умов, який базується на гіпотезі розкладання змінних теплових навантажень на відносно стабільну складову, як базову для вибору встановленої холодопродуктивності ХM, яка працює з високою енергетичною ефективністю на номінальному або близьких йому режимах, і нестабільне теплове навантаження, що припадає на попереднє охолодження зовнішнього повітря при його мінливих поточних температурах. При цьому раціональну базову відносно стабільну складову загального теплового навантаження СКПП визначають виходячи 3 отримання максимального (близького їй) річного виробітку холоду (річний холодопродуктивності), а забезпечує покриття нестабільних (часткових) режимів навантаження, розраховують за залишковим принципом як різниця раціонального сумарного теплового навантаження СКПП і його базової стабільної складової.

\section{Література}

1. Marque, R.P. Thermodynamic analysis of trigeneration systems taking into account refrigeration, heating and 
electricity load demands [Text] / R.P. Marques, D. Hacon, A. Tessarollo, J.A.R. Parise. - Energy and Buildings. 2010. - Vol. 42. - pp. 2323 - 2330.

2. Ortiga, J. Operational optimisation of a complex trigeneration system connected to a district heating and cooling network [Text] / Ortiga Jordi, Bruno Joan Carles, Coronas Alberto. - Applied Thermal Engineering. - 2013. Vol. 50. - pp. 1536 - 1542.
3. Трушляков, Е. И. Методологический подход к энергосберегающему хладоснабжению систем кондиционирования воздуха адаптацией к текущим климатическим условиям / Е.И. Трушляков //Авиационно-космическая техника и технология. - 2018. - № 4(148). - С. 58-62.

\title{
Approach to determine the components of ambient air conditioning system heat load
}

\author{
E. I. Trushliakov, M. I. Radchenko, A. A. Zubarev, V. S. Tkachenko \\ Admiral Makarov National University of Shipbuilding, Mykolaiv, Ukraine
}

\begin{abstract}
An approach to determine the components of ambient air conditioning system (AACS) heat load (a rational heat load on the air conditioning system) with taking into account the current climatic conditions of operation, that is based on the hypothesis of sharing the current changeable heat loads on the relatively stable share as basic one for choosing installed (design) refrigeration capacity of refrigeration machine, operating in nominal or close it modes, and unstable heat load, corresponding to ambient air precooling at changeable current temperatures, is proposed. To prove the approach to determine the components of heat load on the AACS the current values of heat loads on the refrigeration machine of AACS during cooling the ambient air from its changeable current temperature to the temperature of 10, 15 and $20^{\circ} \mathrm{C}$ are analyzed. It is shown that because of different rates of annular refrigeration capacity production increment to cover the current heat loads with increasing the installed refrigeration capacity of refrigeration machine, caused by the changes in heat load according to current climatic conditions during all the year round, it is necessary to choose a such heat load on the refrigeration machine of AACS (its installed refrigeration capacity), that provides a maximum or close it annular refrigeration capacity production at relatively high rates of its increment. With this a value of heat load for ambient air precooling is calculated according to remained principle as difference between the rational total heat load and its basic relatively stable share. The proposed method is useful for determining a basic installed refrigeration capacity of refrigeration machine of AACS, operating in nominal or close it modes, and booster heat loads for ambient air precooling at changeable current temperatures covered by using some energy saving methods: with accumulation of excessive (unused) refrigeration capacity at lowered current heat loads on AACS and its using for ambient air precooling, by recuperation of exhaust air refrigeration capacity with precooling incoming ambient air and others.
\end{abstract}

Keywords: conditioning, ambient air, heat load, refrigeration machine, climatic conditions.

\section{References}

1. Marques, R. P., Hacon, D., Tessarollo, A., Parise, J.A.R. (2010) Thermodynamic analysis of trigeneration systems taking into account refrigeration, heating and electricity load demands. Energy and Buildings, Vol. 42, pp. $2323-2330$.

2. Ortiga, J., Bruno, J.C., Coronas, A. (2013) Operational optimisation of a complex trigeneration system connected to a district heating and cooling network. Applied Thermal
Engineering, Vol. 50, pp. 1536 - 1542.

3. Trushliakov E.I. (2018) methodological approach to energy saving cold supply of air conditioning system by matching current climatic conditions. Aerospace technics and technology, No. 4(148), pp. 58-62. 